\title{
IDŐJÁRÁS
}

Quarterly Journal of the Hungarian Meteorological Service

Vol. 122, No. 2, April-June, 2018, pp. 159-176

\section{Expected changes in the length of Anopheles maculipennis (Diptera: Culicidae) larva season and the possibility of the re-emergence of malaria in Central and Eastern Europe and the North Balkan region}

\author{
Attila J. Trájer ${ }^{1,2^{*}}$, Tamás Hammer ${ }^{3}$ \\ ${ }^{1}$ Institute of Environmental Engineering, \\ University of Pannonia, \\ Egyetem Str. 10, H-8200 Veszprém, Hungary \\ ${ }^{2}$ Department of Limnology, University of Pannonia, \\ Egyetem Str. 10, H-8200 Veszprém, Hungary \\ ${ }^{3}$ Independent author
}

*Corresponding authorE-mail: trajer.attila@mk.uni-pannon.hu, attilatrajer@gmail.com

(Manuscript received in final form April 6, 2017)

\begin{abstract}
Anopheles maculipennis is one of the potential vectors of Plasmodium vivax caused malaria in Europe. Although potential malaria vectors are present in the continent, malaria was eradicated in historical times and recently absent in Central and East Europe and the North Balkan. Climate change may trigger the re-emergence of malaria in Europe positively affecting the seasonal patterns of the potential Anopheline vectors. The increasing length of the larva season of mosquito vectors is one of the risk factors of the re-emerging of malaria. The monthly relative abundance values of the larvae of Anopheles maculipennis were modeled for the reference period 1961-1990 and the periods 2011-2040 and 2041-2070 based on the REMO climate model for Central and East Europe and the North Balkan region. Strong, significant correlation $\left(\mathrm{r}^{2}=0.94, \mathrm{p}<0.0001\right)$ was found between the monthly relative abundances of larvae and monthly mean air temperature values in Hungary between March and November. The threshold of the larval activity of Anopheles maculipennis was found to be about $4{ }^{\circ} \mathrm{C}$. Comparing the modeled relative abundances for 1961-1990, 2011-2040, and 2041-2070, April and October months showed the most notable changes. The model predicts that in Southeast Hungary, East Croatia, North Serbia, South Romania, and North Bulgaria, the main season will increase by +1 to +2 months to the period of 2041-2070 comparing to the reference period. The model also indicates that the complete main Anopheles maculipennis larva season of the mosquito will increase by two months in Southeast Hungary and at least 1 month in the other parts of the south Pannonian Ecoregion, in the North Balkan region including South Romania and North Bulgaria for 2041-2070.
\end{abstract}

Key-words: ecological modeling, mean monthly temperature, Carpathian Basin, malaria mosquitoes 


\section{Introduction}

Anopheles (Cellia) maculipennis s. s. Meigen, 1818 (hence simply: An. maculipennis), the name-giving species of the Anopheles maculipennis complex is abundant in Europe, the Middle East, and the Caucasus. An. maculipennis is the vector of Batai, Tahyna, Myxoma and West Nile viruses, Dirofiliaria immitis Leidy, 1856 and Dirofilaria repens Railliet and Henry, 1911 roundworms and Francisella tularensis McCoy and Chapin, 1912; Dorofe'ev, 1947 (Șuleșco et al., 2016; Silbermayr et al., 2014; Huhtamo et al., 2013; Reusken et al., 2011; Filipe et al., 1972). An. maculipennis and Anopheles (Cellia) messae Falleroni, 1926 were the primarily vectors of malaria in the warm and temperate continental climate areas of Europe ( $D f a, D f b$ zones according to the Köppen-Geiger climate classification) in historical times (Bruce-Chwatt and Zulueta, 1980; Proft et al., 1999). In the warm Mediterranean (summer dry) and humid Mediterranean (subtropical) climate areas ( $\mathrm{Cs} a, C f a$ zones according to the Köppen-Geiger climate classification), rather the malaria mosquitoes Anopheles (Cellia) sacharovi Favre, 1903, Anopheles (Cellia) superpictus Grassi, 1899, and Anopheles (Cellia) labranchiae Falleroni, 1926 were the principal vectors of malaria before the middle of the 20th century (Sinka et al., 2010; Gratz, 2004; Kiszewski et al., 2004). In Greece and the Middle East where malaria is present in the recent times, the members of the Anopheles superpictus complex are important, but not the solely anopheline vectors of malaria (Danis et al., 2011; Oshaghi, 2008), since An. maculipennis is also among those mosquito species which are thought to be the potential recent vectors of Plasmodium vivax Grassi and Feletti, 1890 (Danis et al., 2011).

In the Roman era and the Middle Ages, the mainly P. vivax caused malaria was common autochthonous vector-borne infection in the warmer (Mediterranean and oceanic) climate areas of the Old Continent. Malaria infected the human populations of the Mediterranean region (Facchini et al., 2004; Hume, 2003) or the British Islands (Gowland and Western, 2012), and malaria was a constant scourge in Roman Italy, including the capital of the Roman Empire (Temin, 2006). There are evidences, that Plasmodium falciparum Welch, 1897 caused malaria spread only during the late antiquity era in the Mediterranean (Sallares et al., 2004). Based on the risk classification of Gething et al. (2010), in 1900, malaria was mesoendemic in the Balkan (excluding the high Dinarids and the Rodope Mountains) and the Hungarian Great Plain and hypoendemic in the other areas of Eastern and Central Europe. In Hungary, at least three potential malaria vector species - namely An. maculipennis, Anopheles (Anopheles) atroparvus Van Thiel, 1927 and Anopheles (Cellia) messae Falleroni, 1926- have been collected in the last decades and the presence of a fourth malaria vector mosquito, An. superpictus is also plausible in the southern parts of the country (Tóth and Kenyeres, 2012). Before 1960, malaria was endemic in Hungary (Mihályi and Gulyás, 1963) and 
the pathogen of the recurrent malaria $-P$. vivax - was the most frequently transmitted malaria pathogen (Trájer et al., 2016). The eradication of malaria was performed through several complex, chemical, hydrological, and epidemiological interventions (Szénási et al., 2003). After the eradication of autochthonous malaria, the annual incidences of imported malaria were less than 0.1 per 100,000 inhabitants in the last two decades in Hungary (Chakarova et al., 2015). In Europe, malaria is endemic recently only in Greece, where $P$. vivax protozoans cause autochthonous cases (Danis et al., 2011).

Nowdays, malaria is still one of the most important vector-borne diseases with global distribution causing more than 300-500 million new cases every year in the world (Olupot-Olupot and Maitland, 2013; Caminade et al., 2014; WHO, 2002). About $40 \%$ of the people of Earth live in malaria endemic areas (Mendis et al., 2001), and only in 2015, malaria caused more than 200 million new cases and resulted about 440 thousand deaths worldwide (World Malaria Report, 2015). Despite all efforts, $P$. falciparum caused malaria remained the most important mortality factor for children in the sub-Saharan Africa throughout the entire 20th century (Craig et al., 1999).

The current geographic range of malaria is much smaller than the range of the potential mosquitoes, which phenomena is called as 'Anophelism without malaria' (Jetten et al., 1996). The malaria vector potential of an anopheline mosquito species in a currently malaria-free area is problematic compared to the areas where malaria is still autochthonous. For example, Sinka et al. (2010) found that An. messeae could be the dominant vector of malaria in Central and East Europe; Kiszewski et al. (2004) proposed that An. atroparvus should be the most notable potential malaria vector in the same area. In contrast, based on faunistic studies, in Hungary, it seems that An. maculipennis is one order of magnitude more frequent potential malaria vector mosquito than An. messeae and two-three magnitudes more abundant than An. atroparvus and Anopheles (Anopheles) algeriensis Theobald, 1903. Based on the results of the mosquito collection surveys in the 1960's to the 1990's, An. maculipennis formed itself the 3\% of the total imago mosquito material and more than the $6 \%$ of the larva material (Tóth, 2004), thus it is the most abundant malaria mosquito in the country. It should be added, that there is experimental evidence that Anopheles (Cellia) plumbeus Stephens, 1828 also can transmit human pathogen Plasmodium parasites to human beings (Krüger et al., 2001), which species also occur and frequent in Central and East Europe.

The range of malaria is strongly determined by the occurrence of the anopheline vectors and the seasonal activity patterns of both larvae and imagoes of malaria mosquitoes. Hackett and Missiroli (1935) already in 1935 recognized that the length of the An. maculipennis season is determined by latitude which correlates to the spatial patterns of temperature conditions. Kuhn et al. (2002) found significant relationships between climatic factors as precipitation, temperature and the presence of the most important malaria vectors in Europe. 
The analysis of the former malaria data of Hungary showed that the observed annual run of the incidences of $P$. vivax caused by can be well modeled by the temperature-based activity model of the resident malaria mosquitoes, e.g., the activity of An. messeae (Trájer and Hammer, 2016) indicating+ the importance of ambient temperature on malaria incidence under continental climate conditions.

Now, global climatic change is expected to increase the range and incidence of mosquito- and other arthropod-borne diseases. Climate scenarios predict the increase of temperature, which can increase the risk of the parasite transmissions by increasing the distribution and abundance of vectors, and the length of mosquito vector and parasite seasons (Russel, 1998). The effect of climate change on the distribution of malaria mosquitoes is not a fiction: in the period of 19732012, the expansion of An. maculipennis was observed in northeastern Europe and northwestern Asia (Novikov and Vaulin, 2014). Parallel to the spread of the vectors, one of the possible results of elevated temperature conditions is the increasing worldwide burden and distribution of malaria (Lindsay and Birley, 1996; Loevinsohn, 1994). Martens et al. (1999) predicted that the greatest potential consequences of climate change are that malaria will occur in temperate zones, where the anopheline mosquito vectors are present but the recent cooler climate does not allow the transmission of the parasites. Kuhn et al. (2002) showed that climate change can significantly increase the abundance of the European Anopheles species.

The investigation of the potential effect of climate change on mosquito larva seasonality can help the development of the near-future mosquito-control protocols. In nature, mosquito populations originally were limited by their predators including, e.g., the predation of swallows (Brown and Sethi, 2002). In human environment, the decrease of mosquito abundance has serious health and veterinary importance in the mosquito-vectored-endemic areas of the world (Reiter, 2001; Rogers and Randolph, 2000; Patz et al., 1998). The abundance of mosquito-borne diseases also depends on the urbanization intensity (Trájer et al., 2016). The activity of malaria vectors and the seasonal transmission probability of Plasmodium species are highly sensitive to climatic conditions (Martens et al., 1995) - mainly the changes of temperature (van Lieshout et al., 2004). Similarly to the larvae of other anopheline mosquitoes, the larvae of An. maculipennis also develop through four instars, after which they metamorphose into pupae. The time of development is the function of water temperature where larvae develop, and it indirectly depends on the ambient air temperature. It is known, that elevated ambient temperatures increase the growth rates of mosquito vector populations, since the full ontogeny time of mosquitoes depends on temperature ( $P a z$ and Albersheim, 2008). The larvae of An. maculipennis can inhabit the water of smaller watercourses, marshes, brooks, rainwater puddles, and the littoral part of small lakes, or they can live even in dendrotelmata, fitotelmata, technotelmata, or malakotelmata. In the Bakony-Balaton region, Hungary, larvae were continuously 
collected from the beginning of April to mid-October, and the main swarming season of imagoes occurred from late June to the end of September (Tóth 2006). The species avoid the salt lakes of the Hungarian Great Plain (Tóth, 2004).

We aimed to model the changing seasonality of An. maculipennis larvae due to climate change in Central and East Europe and the North Balkan region based on the scenarios of the REMO climate model. We focused on the modeling of the start and end of the mosquito larva season of An. maculipennis. It was hypothesized, that the Carpathian Basin is one of the most sensible areas to the anthropogenic climatic change also in the aspect of the changing seasonality patterns of An. maculipennis. The seasonal abundance of An. maculipennis imagoes practically overlaps with the seasonality of larvae in Hungary. About more than five times higher numbers of larvae were collected than imagoes (2258/12363; Tóth, 2004). The higher number of larvae provided more confident correlation between the abundance and temperature.

On the other hand, mosquito larvae are target of the modern biological mosquito control techniques. The populations of mosquito larvae can be reduced by biological control agents, which methods are more selective than the classical pesticide-like adulticides, which chemicals are harmful for the ecosystems in general. The modeling of the predictable seasonality of An. maculipennis larvae can help the future mitigation procedures. In the interpretation of the results, we focused also on the biological and social consequences of the changing spatialtemporal patterns of An. maculipennis larvae, and we analyzed the probability of the re-emergence of malaria in the light of our findings.

\section{Materials and methods}

\subsection{Mosquito data}

The monthly mosquito larva data of An. maculipennis were gained from the mosquito monograph of Tóth (2004). This monograph contains the data of different mosquito larvae, pupae, and adults based on the literature of the former mosquito collection efforts in Hungary and the author's own surveys. The monograph was based on the data of collections, which were performed basically in the 1960's, 1970's, 1980's, and the 1990's. The abundance data of larvae of An. maculipennis were used in monthly temporal distribution. The absolute number of larvae were converted to relative monthly abundance values according to Eq.(1). If the total annual value is $100 \%$, relative monthly abundance value is

$$
A_{r m}=\frac{N_{m}}{N_{a}} \times 100,
$$


where $A_{r m}$ is the relative abundance of a month, $N_{m}$ is the number of the total collected larvae according to a given month, and $N_{a}$ is the total number of the collected larvae representing the entire period.

\subsection{Climate data and its processing}

It was thought that ambient air temperature can be handled as the principal factor of An. maculipennis seasonality with specific regard to the start and end of the mosquito larva season, and consequently, temperature can strongly influence the total length of the larva season. This presumption was based on the observations that the poikilothermic An. maculipennis mosquitoes breed in small lakes, small lake-like reservoirs, litoprofundal shallow lakes, and swamp-like natural waters (Tóth, 2004), which have low heat storage capacity due to the combination of extent water surface and relatively low water depth. This geometry is expressly true for the narrow littoral zone of the waters, where the larvae of $A n$. maculipennis can be found.

Two climate data sources were used:

1) The REMO model provided climatic analysis for the reference period and two future periods (2011-2040 and 2041-2070) for modeling purposes.

2) Since the collection period of mosquito larvae (from the 1960's to the end of the 1990's - which practically means the period of 1961-1999 in the present analysis) does not completely overlap the reference period of the REMO model (1961-1990), the E-OBS climate model (from 1950 to now) was used for the preformation of correlation between monthly relative mosquito larva abundances and monthly mean temperature values.

European climate data were obtained from the regional climate model REMO, which was developed in Hamburg (Jacob et al., 1997; Jacob, 2001). The horizontal resolution of the used grid is $25 \mathrm{~km} \times 25 \mathrm{~km}$. The model REMO is based on the ECHAM5 global climate model (Roeckner et al., 2003, 2004) and the IPCC SRES A1B scenario. The A1B scenario supposes very fast economic increase, worldwide population peak in the middle of the 21 st century, and the introduction of innovative and efficient technologies (Nakicenovic and Swart, 2000). The reference period of REMO is 1961-1990, the two future periods of modeling are 2011-2040 and 20412070. Although the entire European continent is within the domain of REMO, only a part of the grid shown in Fig. $1 A$ was used. For the abundance modelling, only one variable, the monthly mean temperature $\left({ }^{\circ} \mathrm{C}\right)$ was used.

To perform the correlation between the relative (\%) abundance values and mean temperatures, mean temperature values of the period 1961-1999 were gained from the E-OBS model. The monthly ambient temperature values were averaged according to monthly temporal resolution. The following grid was used which covers almost the whole area of Hungary: from 45.75 to $48.50 \mathrm{~N}$ and from 16.00 to $23.00 \mathrm{E}$. The spatial resolution was $0.25^{\circ} \times 0.25^{\circ}$ (Fig. 1B). 


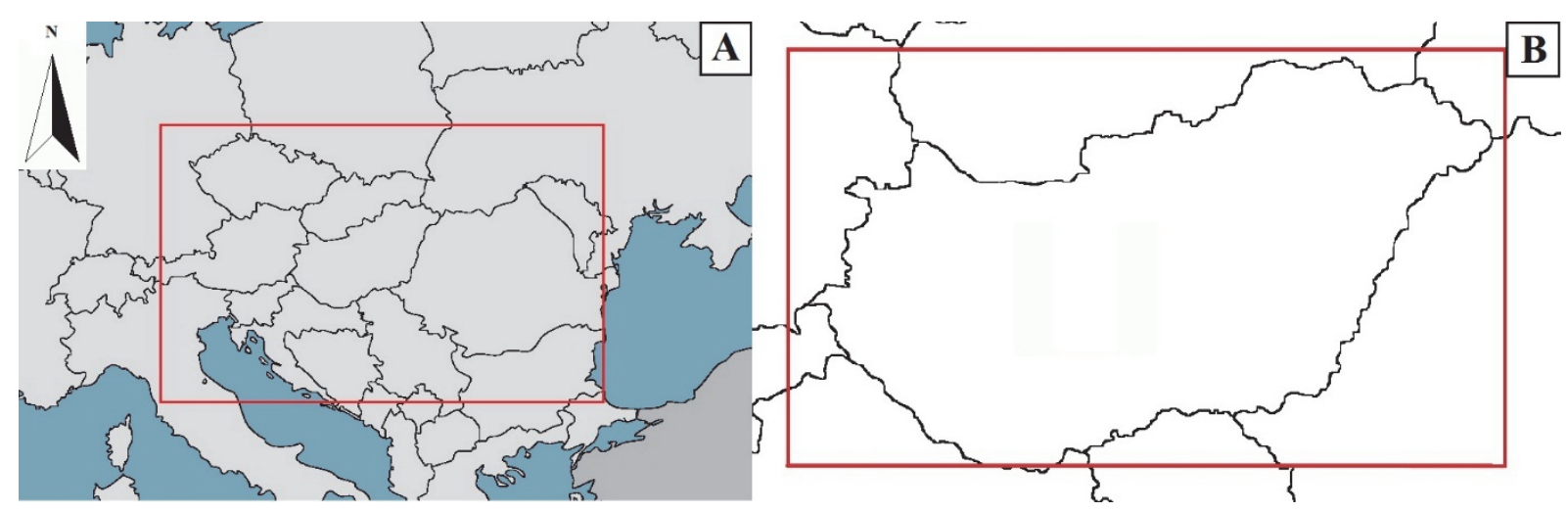

Fig. 1. Domains of the REMO (red rectangle; A) and E-OBS (red rectangle; B) models within of Europe.

\subsection{Modeling steps}

Comparing the relative monthly abundance data of the larvae of An. maculipennis and the monthly mean temperature values, it was observed, that the annual abundance profile of the mosquito larvae starts to increase rapidly above the abundance value of $12 \%$ in May, and inversely, the main season ends, when the abundance decreases below this value after September in Hungary. The 12\% monthly abundance value was handled as the frame of the main larva season of the mosquito. Only those months were involved into the analysis, when the monthly mean temperature of the period exceeded the $4 \mathrm{C}$ value, which empirically indicates the start/end of the larva season.

\section{GIS processing of the data}

ESRI ArcGIS 10.0 software was used for preparing climatic data, running the model, and displaying the model results. First step, the georeferred climate data of REMO climate model were loaded to the program. Using the raster calculator function of ArcGIS, monthly temperature values were converted into monthly relative abundance values based on Eq.(2) (see below). The raster results were converted to polygon-type ESRI shapefile format. The order of the three layers - the modeled relative larva abundance values of the periods 1961-1990, 2011-2040, and 2041-2070 - determined that the result maps can show the mainly northward (spring), southward (autumn), or the seasonal altitudinal shifts of the relative abundance (or activity) of An. maculipennis larvae. To create color images, we linked the points with the calculated relative abundance values. The different values were assigned to the referred points and were sorted into attribute table. Then the climatic data were refined by the inverse distance weighted interpolation method of ESRI ArcGIS 10 software. Color codes of relative abundance values were selected according to a 0 to 12 (exactly to $12.24<$ ) scale. Dark red color was used to mark the main season in the maps, when the modeled relative abundance values reach or exceed the $12 \%$ annual value; porcelain white color indicate the pre or post-season areas, where there are no active larvae in the natural waters. 


\section{Results}

\subsection{Correlation between the monthly relative larva abundances and the temperature}

The start of the main season was in April, while the threshold of the larval abundance of An. maculipennis was about $4 \mathrm{C}$ in Hungary in the reference period. In the end of the season, the monthly abundance value decreased below the $12 \%$ value which occurred in October, while the larval season ended in November in the reference period in Hungary, when the ambient mean temperature sank below 4 C (Fig. 2).

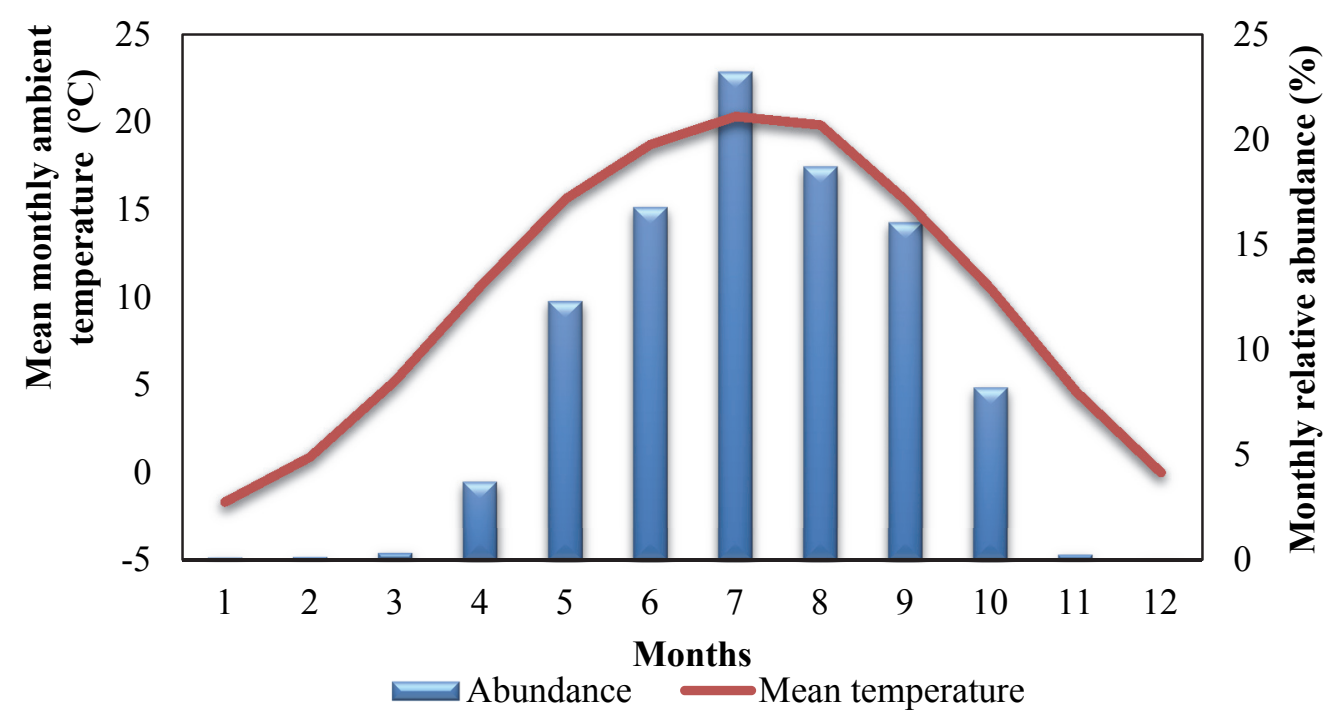

Fig. 2. The run of the monthly relative abundances of An. maculipennis larvae in Hungary based on the collected mosquito material of the 1960's to 1990's, and the run of the mean monthly ambient temperature in 1961-1999 averaged according to the selected grid of Hungary.

Strong, significant linear correlation was found between the monthly relative abundances of larvae and the mean ambient temperature values $\left(\mathrm{r}^{2}=0.94\right.$, $\mathrm{p}<0.0001$ ) from March to November:

$$
A_{r m}=1.3564 * T_{m}-7.1749,
$$

where $A_{r m}$ is the relative (\%) abundance of An. maculipenis larvae in a month, $T_{m}$ is the mean monthly ambient temperature $\left({ }^{\circ} \mathrm{C}\right)$. Eq.(2) was used in the modeling if the projected abundance of the larvae (Fig. 3). 


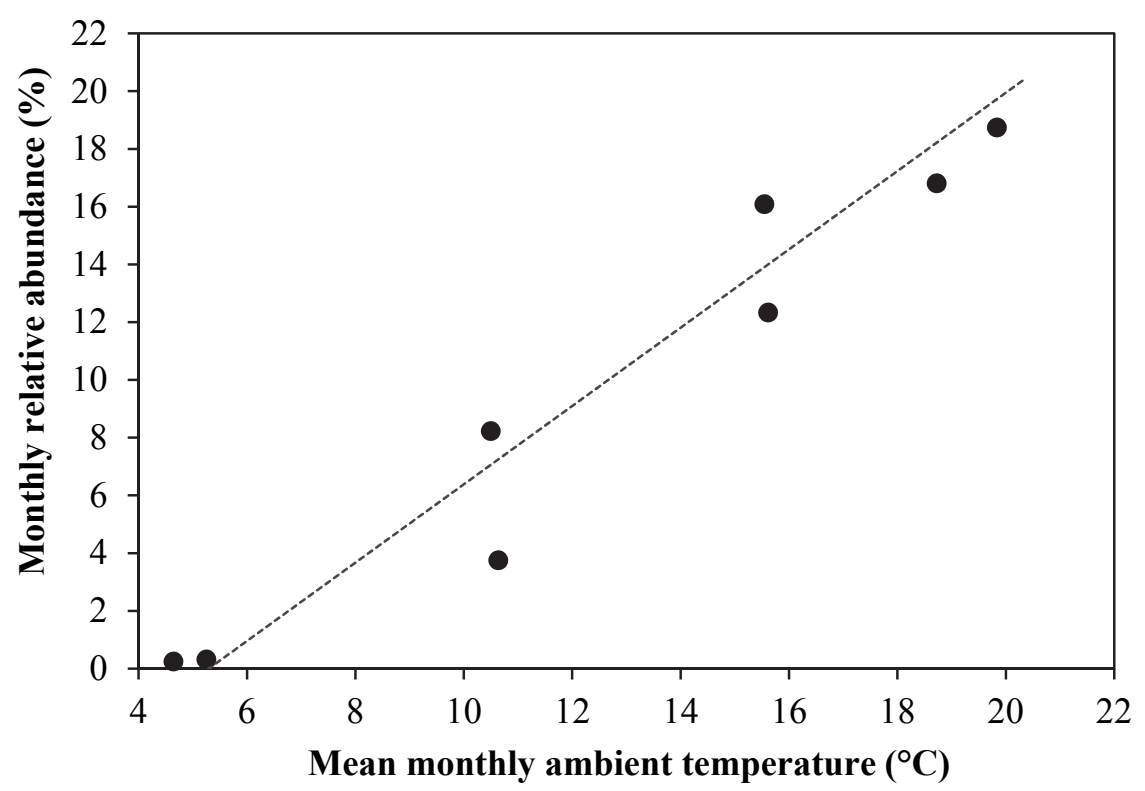

Fig. 3. The correlation between the monthly relative abundances of An. maculipennis larvae and the mean monthly ambient temperatures in March to November.

\subsection{Modeled starts of the seasons}

The modeled relative abundance values of An. maculipennis larvae showed notable differences in the case of the three different 30 -year periods. Comparing the modeled abundances for the reference periods 1961-1990, 2011-2040, and 2041-2070, the most notable spatio-temporal shifts in the main larval seasonality - including the start of the absolute and the main season - was observed in April based on the modeled relative abundances. It was modeled for the reference period, that the main larva season usually did not start until May in Central and East Europe and the North Balkan region except a Romanian lowland section of river Danube. In contrast, for the period 2011-2041 the model predicts, that the main season of the larvae of An. maculipennis will start in April in the areas of Vojvodina, Serbia and the Romanian Lowland. For the period 2041-2070, the model predicts broader shift of the main season's start from May to April affecting almost the entire South Pannonian Ecoregion. In Southeast Hungary, East Croatia, North Serbia, South Romania, and North Bulgaria, the total main season will shift by 1 month to the period of 2041-2070. For 2041-2070, the model predicts that the start of the season of the mosquito's larvae in Southeast Germany, the Czech Republic, and the northeastern forelands of the Carpathian Mountains will start one month earlier compared to the reference period (Fig. 4). 


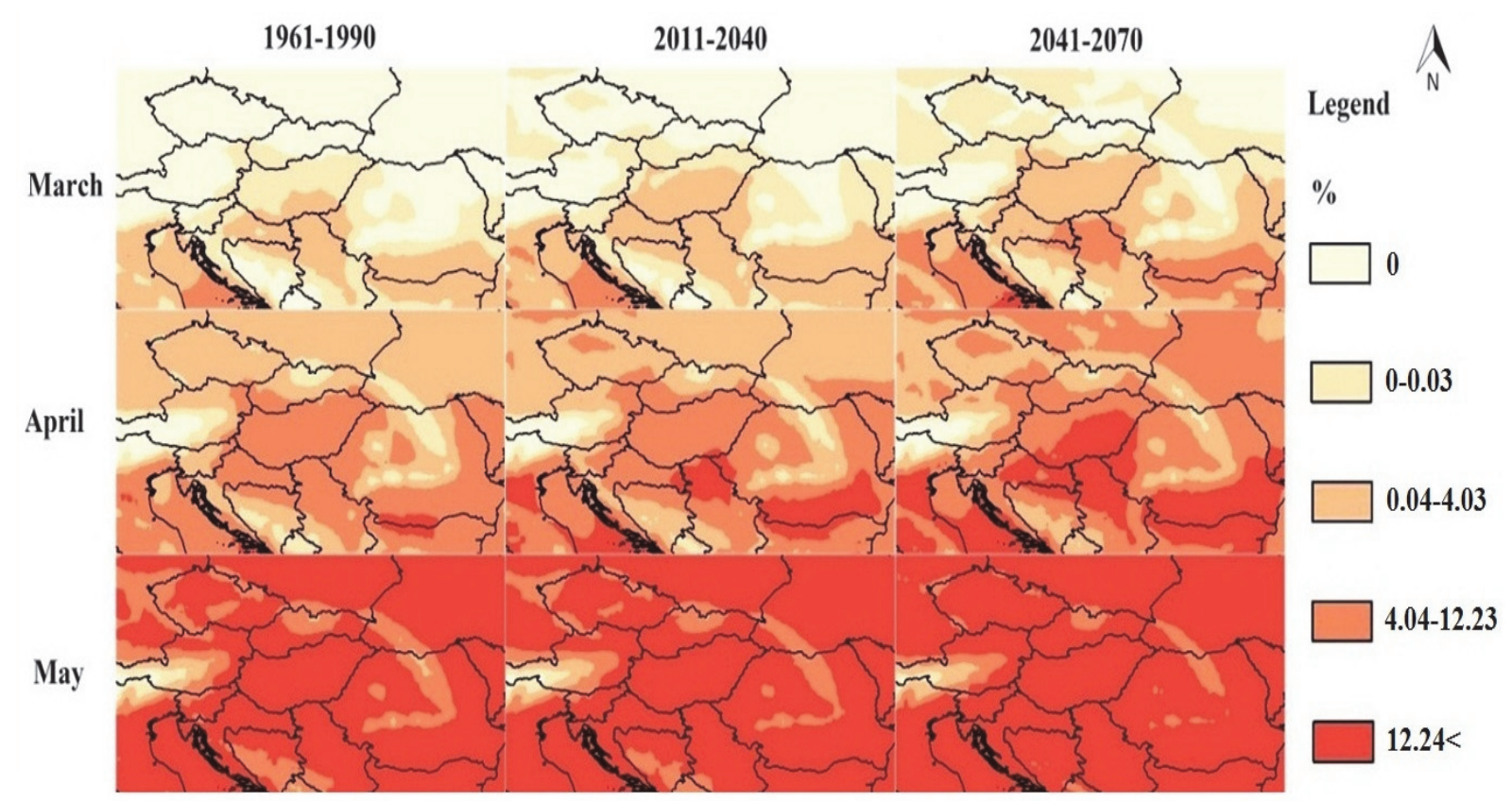

Fig. 4. The predicted monthly relative abundance values of An. maculipennis larvae in Central and East Europe and the North Balkan in March, April and May for the periods of 1961-1990, 2011-2040, and 2041-2070.

\subsection{Modeled ends of the seasons}

The model predicts that the main season of An. maculipennis larvae will end one month later in 2041-2070, compared to the reference period, when it ends in October. For 2041-2071, the model predicts that the total season will not end until November in the northern part of Central Europe. For 2041-2070, the model predicts also that the main season of the mosquito's larvae will continue to the end of October in the entire North Balkan and South Pannonian Ecoregion to the end of October. In Hungary, the end of the main season will shift by plus 1 month for the period 2041-2070. Due to the high heat storage capacity of the sea water, the main season of An. maculipennis continues to November in the Adriatic coasts. For 2041-2070, the model predicts that the start of the season of the mosquito's larvae in South East Germany, the Czech Republic and the North East forelands of the Carpathian Mountains will end one month later compared to the reference period. The model shows the vertical shift of the season, which is clearly visible in case of the Tranylvanian Middle Mountains. or in the Dinarid Ranges, where the main part of the season also predicted to start earlier and end later by 1-1 month (Fig. 5). 


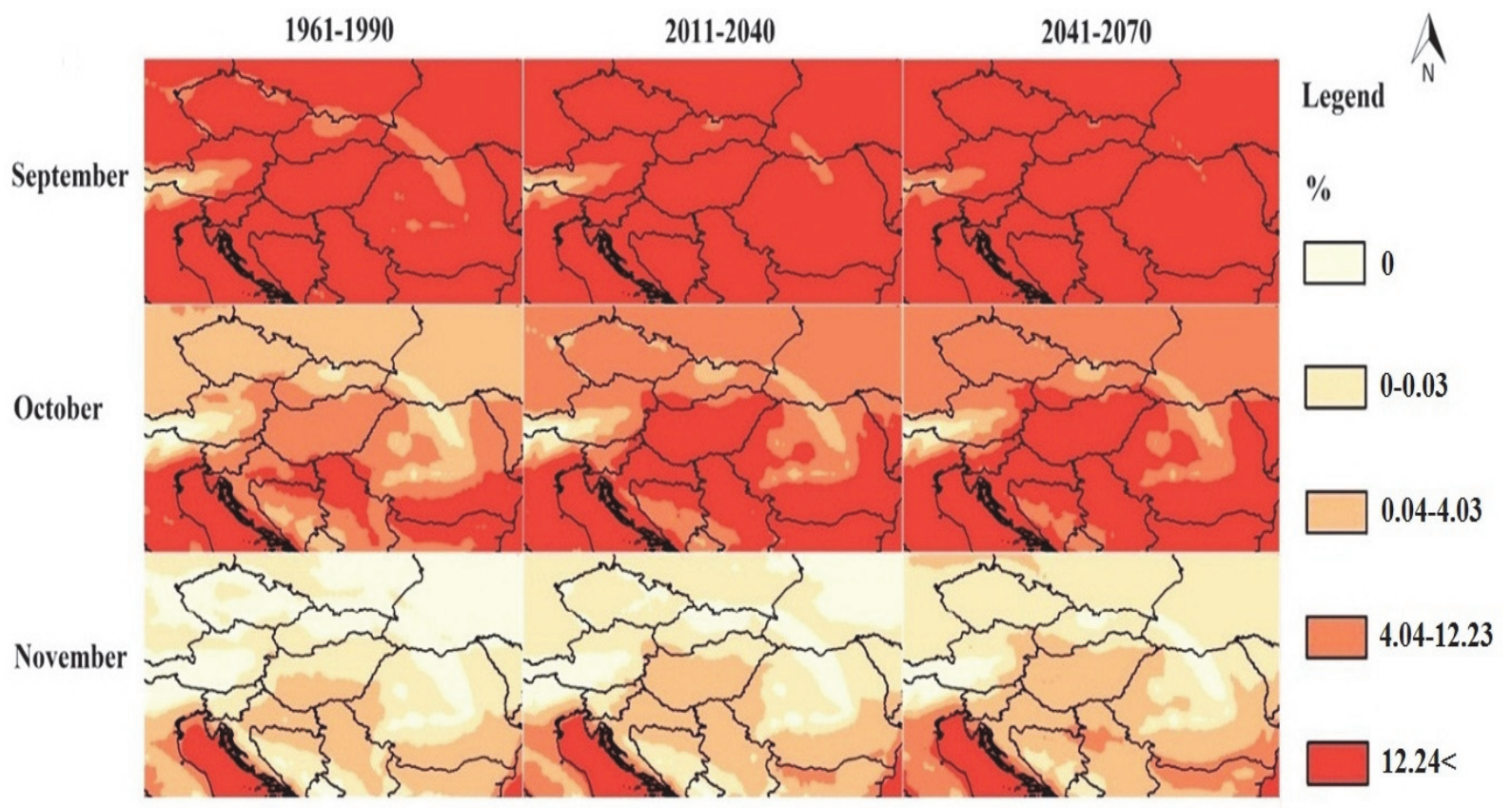

Fig. 5. The predicted monthly relative abundance values of An. maculipennis larvae in Central and East Europe and the North Balkan in September, October and November for the periods of 1961-1990, 2011-2040, and 2041-2070.

\section{Discussion}

The monthly relative abundance values of An. maculipennis larvae was modeled for 1961-1990, 2011-2040 and 2041-2070 in Central and East Europe and the North Balkan region based on the REMO climate model and the Hungarian monographic mosquito data of Tóth (2004). Our results predict the notable elongation of the larva season for 2011-2040 and 2041-2070 compared to the reference period 1961-1990. The changes of the geographical patterns of the starting and ending months of the main and absolute seasons seem to be not homogenous in the studied region. The fastest increase of the season's length will affect the areas, where large rivers and flood basins occur. The model predicts the most rapid elongation of the larva season of An. maculipennis in the central part of the Pannonian Ecoregion and the lower (Romanian and Bulgarian) section of the Danubian Plain. The model shows that the length of the main season is predicted to increase by 2 months for 2041-2070 in the southeastern part of the Hungarian Great Plain, while in the other parts of the Pannonian Ecoregion and the North Balkan, the length of the main season will elongate by less than two months for the second future period. These heterogenic predicted spatial-temporal changes of the activity of larvae can be the potential consequence of the faster warming climate of the Carpathian Basin (and some other floodplain areas in the North Balkan) compared to the other regions of Europe (Bartholy and Gelybó, 2007). 
The above summarized results support the hypothesis that meteorological/ climatic factors, as ambient temperature, influence substantially the spatialtemporal activity patterns of the potential vectors, and indirectly the transmission dynamics of vector-borne diseases such as malaria (Githeko et al., 2000; Gubler, 1998; and Gubler et al., 2001). This conclusion is highly true for mosquitoes and mosquito-borne infections (Reiter, 2001). The temperature threshold of the vital and blood meal seeking activity of female mosquitoes are different that is also can be true for physiological thresholds of the vector mosquitoes and the transmitted protozoans. The temperature threshold of the digestion of blood meal in case of An. maculipennis is about $10{ }^{\circ} \mathrm{C}$, while the threshold temperature of the extrinsic incubation cycle of $P$. vivax is about $15{ }^{\circ} \mathrm{C}$ (Martens et al., 1995). Comparing the thresholds of the activity of An. maculipennis imagoes and the extrinsic incubation cycle of the different Plasmodium species indicate that the length of the malaria season should be shorter than the potential season of adults or larvae. Based on these facts, the effect of the increasing length of the larval seasonality of An. maculipennis on the malaria risk cannot be clearly estimated due to the non-linear response of the vector-parasite-host system (Patz and Olson, 2006). This non-linear correlation reflects in the results of some authors, who found that the elongation of the malaria mosquito season rather increases the risk of malaria transmission in the future in the temperate areas than in the subtropical or tropical regions of the Earth (Martens and Thomas 2005; Martens et al., 1995). In addition, the increasing length and frequency of above-average summer temperatures in association with heat waves due to climate change also may has unexpected positive impact on malaria transmission (Baldari et al., 1998, Krüger et al., 2001). Climatic change also can cause the redistribution of the dominant malaria vectors in the temperate zone of Europe, although this topic has not been studied sufficiently yet.

The number of annual mosquito generations - which primarily depends on the length of the mosquito season - substantially influences the total number of mosquitoes and the human-infected mosquito encounter probability. The exact estimation of the generation number of a mosquito should require the calculation of the temperature-based development time of each ontogeny stages, as in case of the potential annual generation number of Aedes (Stegomyia) albopictus Skuse, 1894 was modeled under different climatic circumstances by Trájer et al. (2017). The effect of the precipitation conditions on mosquito vector's abundances is controversial and highly depends on species, climate, month, and geographical location (Landesman et al., 2007), but does not affect substantially the length of the season of mosquitoes in temperate areas, where appropriately small water habitats are available during the entire year - except in very severe droughts.

In fact, in Hungary it was found, that seasonal abundance profile of imagoes overlaps with the season of larvae. It can be explained by the fact that the first annual generation of larvae come from eggs laid by a small number overwintering An. maculipennis females in early spring (Freeborn, 1932), since a little 
proportion of malaria mosquitoes can overwinter in caves and other shelters (Tóth, 2006). As it was mentioned, the correlation between the temperature and the vector-borne diseases - including the malaria risk - follows non-linear correlations, since the biological response of mosquito populations to increasing temperatures can be more than an order of magnitude larger than the observed change in temperature (Patz and Olson, 2006). Lindsay and Birley (1996) also found, that small increases in temperature at low temperatures may increase the risk of transmission radically. Global climate change will have substantial impact on the length of malaria transmission season in several areas, affecting also the temperate countries and the tropical mountains, where recently the climate is too cold for the transmission of malaria (Martens et al., 1999). The length of the activity season of malaria mosquitoes is one of the important risk factors, and consequently, it also can be the symptom of the warming climate. In addition, Bradly (1989) showed that due to the warming trends of climate, the length of the life cycle of Plasmodium parasites also will be shorter increasing the risk of the transmission of the pathogens.

The analysis of the past autochthonous malaria data of Hungary provided important additive information on the influencing climatic factors of the former temperate malaria (see, e.g., Trájer et al., 2016). However, the derivation of observed malaria seasons from the modeled annual activity of the plausible mosquito vectors can be problematic, since there are sparse reliable data about the exact composition, abundance, and infection rate of the former anopheline mosquito fauna. Summarizing the available data about the past vectors of (the mainly) P. vivax caused malaria, Szénási et al. (2003) found that An. atroparvus, An. maculipennis, and An. messeae were the vectors of the Plasmodium parasites in Hungary before the 1960's. It should be mentioned that the changes of the taxonomy of the An. maculipennis complex trough time and the similarity of these species to each other -causing difficulties in the identification - can cause conceptual and taxonomic confusions in the evaluation of the former literature of temperate malaria vectors. It is a notable problem, because when in the first decades of the 20th century malaria was still endemic in some parts of the temperate climate areas of Europe, the systematics of the Anopheles maculipennis complex was under clarification. While the name-giving An. maculipennis (understand as An. maculipennis sensu lato) already was described in 1818 by Meigen, An. messeae was separated from the other species of the complex only in 1926 by Falleroni. In 1935, Hackett and Missiroli, and in 1940, Bates published their reviews about the taxonomy of the complex. Mihályi and Gulyás (1963) clarified the occurrence and the taxonomic composition of the complex in Hungary.

It should be also added, that the malaria vector status of a mosquito depends on the specific blood meal questing preferences of malaria mosquitoes. The females of An. maculipennis mainly bite other mammals and rather the females of An. atroparvus and An. messeae feed on humans (Kenyeres and Tóth, 2008). These observations cannot be generalized for each of the An. maculipennis 
populations of Central and Eastern Europe. The potential malaria vector role of An. maculipennis (sensu stricto) can be proposed due to the high frequency of the species compared to the total mosquito material. An. maculipennis can be handled as the typical, model-value species of the An. maculipennis complex. Modeling the larval seasonality of this mosquito can be indicative to some other relative species of the complex in the studied region - mainly for An. messeae - and less in the case of An. atroparvus, which is a rather Mediterranean element of the complex. As it was mentioned, in the Balkan Peninsula, where some other potential malaria vectors also exist, An. maculipennis is a secondarily important vector of Plasmodium species in this area. Furthermore, the model value of $A n$. messeae is less obvious in this area concerning the future malaria risk.

The modeling of larval seasonality of potential malaria vectors has further potential positive incomes for the societies and wildlife. In the past, adulticides were almost the solely agents of mosquito control causing significant damages to the ecosystems. If larvicides were applied it meant the use of contact poisons, growth regulators or surface films (as even the use of diesel oil). In the last few decades, the ecological noxiousness of these interventions become clear. The expressed hazard of the use of DDT to the ecosystems is no doubt since the release of Silent Spring (Carson, 1962). The new generation larvicides against anopheline and culicine mosquitoes are hormones, bacterial agents as, e.g., Bacillus thuringiensis Berliner, 1915 serovariety israelensis or Lysinibacillus (Bacillus) sphaericus Neide, 1904 (Lacey, 2007; Lacey and Singer, 1982; Goldberg, 1979), fungi, nematodes, copepods, or aquatic vertebrae (Walker and Lynch, 2007). It is plausible, that the importance of the less harmful mosquito-control agents will increase in the next decades, although the efficacy of, e.g., the bacterial agents depends on the habitat type. Shiliu et al. (2003) described that the bacterial biopesticides against Anopheles larvae were less effective in habitats with high algal content and in fast flowing streams due to the isolating effect of algal mats and the dilution effect of river streams. Along with these tools, models, which are based on the larval seasonality, can represent the progressive approach of the mitigation and adaptation strategies in response to the effect of climate change on anopheline mosquito populations.

\section{Conclusions}

Our model concerned a very important factor of the possible re-emergence of malaria in Central and East Europe, since the length of the mosquito larva season affects the possibility of malaria transmission by several direct and indirect ways. Of course, several other factors can act to the persistence of the autochthonous vector cycle of human malaria. It can be concluded that the changing larva season of An. maculipennis can be used as the indicator of climate change for malaria mosquitoes in the temperate and sub-Mediterranean areas of Central and East 
Europe and the North Balkan. The additional modeling of the future seasonality of Mediterranean Anopheles mosquitoes should be useful in the further estimation of the possibility of the re-emergence of malaria in Europe. Our projection can be used in the planning of the chemical control of mosquito populations helping the adaptation and mitigation for the future warmer climate of Europe, since mosquito larvae are the targets of the selective biological control agents.

Acknowledgement: This study was supported by the Hungarian National Research, Development and Innovation Office (NKFIH K120595). The study was supported also by EFOP-3.6.1-16-2016-00015 and GINOP-2.3.2-15-2016-00016.

\section{References}

Baldari, M., Tamburro, A., Sabatinelli, G., Romi, R., Severini, C., Cuccagna, G., Fiorilli, G., Pia Allegri, M., Buriani, C., and Toti, M., 1998: Malaria in Maremma, Italy. The Lancet 351, 1246-1247. https://doi.org/10.1016/S0140-6736(97)10312-9

Bartholy, J. and Gelybó, R.P.G., 2007: Regional climate change expected in Hungary for 2071-2100. Appl. Ecol. Environ. Res. 5, 1-17. https://doi.org/10.15666/aeer/0501_001017

Bates, M., 1940: The nomenclature and taxonomic status of the mosquitoes of the Anopheles maculipennis complex. Ann. Entomolog. Soc. Amer. 33, 343-356. https://doi.org/10.1093/aesa/33.2.343

Bradley, D.J., 1989: Current trends in malaria in Britain. J. Roy. Soc. Medic. 82, 8-13.

Brown, C.R. and Sethi, R.A., 2002: Mosquito abundance is correlated with cliff swallow (Petrochelidon pyrrhonota) colony size. J. Medical Entomol. 39, 115-120. https://doi.org/10.1603/0022-2585-39.1.115

Bruce-Chwatt, L.J. and De Zulueta, J., 1980: The rise and fall of malaria in Europe: a historicoepidemiological study. Published for the Regional Office for Europe of the World Health Organization by Oxford University Press, Walton Street, Oxford OX2 6DP.

Caminade, C., Kovats, S., Rocklov, J., Tompkins, A.M., Morse, A.P., Colón-González, F.J., Stenlund, H., Martens, P., and Lloyd, S.J., 2014: Impact of climate change on global malaria distribution. Proc. Nat. Acad. Sci. 111, 3286-3291. https://doi.org/10.1073/pnas.1302089111

Carson, R., 1962: Silent spring. Houghton Mifflin Company.

Chakarova, B., Kichukova, K., and Karaslavov, G., 2015: A short historical overview of malaria in worldwide and in Bulgaria. The fight against malaria-the main task of sanitary epidemiological station in stara zagora in the first year of its opening, 1950. Trakia J. Sci. 13, 151-154. https://doi:10.15547/tjs.2015.s.02.032

Craig, M.H., Snow R.W., and Le Sueur, D., 1999: A climate-based distribution model of malaria transmission in sub-Saharan Africa. Parasitology today 15, 105-111. https://doi.org/10.1016/S0169-4758(99)01396-4

Danis, K., Baka, A., Lenglet, A., van Bortel, W., Terzaki, I., Tseroni, M., Detsis, M., Papanikolaou, E., Balaska, A., Gewehr, S., Dougas, G., Sideroglou, T., Economopoulou, A., Vakalis, N., Tsiodras, S., Bonovas, S., and Dougas, G., 2011: Autochthonous Plasmodium vivax malaria in Greece, 2011. Eurosurveillance 16, 1-5.

Facchini, F., Rastelli, E., and Brasili, P., 2004: Cribra orbitalia and cribra cranii in Roman skeletal remains from the Ravenna area and Rimini (I-IV century AD). Int. J. Osteoarchaeol., 14, 126-136. https://doi.org/10.1002/oa.717

Filipe, A.R., 1972: Isolation in Portugal of West Nile virus from Anopheles maculipennis mosquitoes. Acta virologica 16, 361-361.

Freeborn, S.B., 1932: The seasonal life history of Anopheles maculipennis with reference to humidity requirements and" hibernation.". Amer. J. Hygiene 16.

https://doi.org/10.1093/oxfordjournals.aje.a117857 
Gething, P.W., Smith, D.L., Patil, A.P., Tatem, A.J., Snow, R.W., and Hay, S.I., 2010. Climate Change and the Global Malaria Recession. Nature 465, 342-346.

https://doi.org/10.1038/nature09098

Githeko, A.K., Lindsay, S.W., Confalonieri U.E. and Patz, J.A., 2000: Climate change and vector-borne diseases: a regional analysis. Bull. World. Health. Organ. 78, 1136-1147.

Goldberg, L.J., 1979: U.S. Patent No. 4,166,112. Washington, DC: U.S. Patent and Trademark Office.

Gowland, R.L., and Western, A.G., 2012: Morbidity in the marshes: Using spatial epidemiology to investigate skeletal evidence for malaria in Anglo-Saxon England (AD 410-1050). Amer. J. Physical Anthropol. 147, 301-311. https://doi.org/10.1002/ajpa.21648

Gratz, N.G., 2004: The mosquito-borne infections of Europe. Europ. Mosquito Bull. 17, 1-7.

Gubler, D.J., Reiter, P., Ebi, K.L., Yap, W., Nasci, R., and Patz, J.A., 2001: Climate variability and change in the United States: potential impacts on vector-and rodent-borne diseases. Environ. Health Perspectiv. 109, 223. https://doi.org/10.2307/3435012

Gubler, D.J., 1998: Resurgent vector-borne diseases as a global health problem. Emerging Infectious Diseases 4, 442. https://doi.org/10.3201/eid0403.980326

Hackett, L.W., and Missiroli, A., 1935: The varieties of Anopheles maculipennis and their relation to the distribution of malaria in Europe. Rivista di Malariologia, 14, 46-109.

Huhtamo, E., Lambert, A.J., Costantino, S., Servino, L., Krizmancic, L., Boldorini, R., Allegrini, S., Grasso, I., Korhonen, E.M., Vapalahti, O., and Lanciotti, R.S., 2013: Isolation and full genomic characterization of Batai virus from mosquitoes, Italy 2009. J. General Virology 94, 1242-1248. https://doi.org/10.1099/vir.0.051359-0

Hume, J., 2003: Malaria in antiquity: a genetics perspective. World archaeol. 35, 180-192. https://doi.org/10.1080/0043824032000111362

Jacob, D., 2001: A note to the simulation of the annual and inter-annual variability of the water budget over the Baltic Sea drainage basin. Meteorol. Atmos. Phys. 77, 61-73. https://doi.org/10.1007/s007030170017

Jacob, D. and Podzun, R., 1997: Sensitivity studies with the regional climate model REMO. Meteorol. Atmos. Phys. 63, 119-129. https://doi.org/10.1007/BF01025368

Jetten, T.H., Martens, W.J.M., and Takken, W., 1996: Model simulations to estimate malaria risk under climate change. J. Medical Entomol. 33, 361-371. https://doi.org/10.1093/jmedent/33.3.361

Kenyeres, Z., and Tóth, S., 2008: Csípőszúnyog határozó II. (Imágók). Pannónia Füzetek 2, 1-96. (In Hungarian)

Kiszewski, A., Mellinger, A., Spielman, A., Malaney, P., Sachs, S.E., and Sachs, J., 2004: A global index representing the stability of malaria transmission. Amer. J. Tropical Medicine Hygiene 70, 486498.

Krüger, A., Rech, A., Su, X.Z., and Tannich, E., 2001: Two cases of autochthonous Plasmodium falciparum malaria in Germany with evidence for local transmission by indigenous Anopheles plumbeus. Tropic. Medicine Int. Health 6, 983-985. https://doi.org/10.1046/j.1365-3156.2001.00816.x

Kuhn, K.G., Campbell-Lendrum, D.H., and Davies, C.R., 2002: A continental risk map for malaria mosquito (Diptera: Culicidae) vectors in Europe. J. Medical Entomol. 39, 621-630. https://doi.org/10.1603/0022-2585-39.4.621

Lacey, L.A., 2007: Bacillus thuringiensis serovariety israelensis and Bacillus sphaericus for mosquito control. J. Amer. Mosquito Control Assoc. 23, 133-163. https://doi.org/10.2987/8756-971X(2007)23[133:BTSIAB]2.0.CO;2

Lacey, L.A. and Singer, S., 1982: Larvicidal activity of new isolates of Bacillus sphaericus and Bacillus thuringiensis (H-14) against anopheline and culicine mosquitoes. Mosquito News 42, 537-543.

Landesman, W.J., Allan, B.F., Langerhans, R.B., Knight, T.M., and Chase, J.M., 2007: Inter-annual associations between precipitation and human incidence of West Nile Virus in the United States. Vector-Borne Zoonotic Diseas. 7, 337-343. https://doi.org/10.1089/vbz.2006.0590

van Lieshout, M., Kovats, R.S., Livermore M.T.J., and Martens, P., 2004: Climate change and malaria: analysis of the SRES climate and socio-economic scenarios. Glob. Environ. Change 14, 87-99. https://doi.org/10.1016/j.gloenvcha.2003.10.009

Lindsay, S.W., and Birley, M.H., 1996: Climate change and malaria transmission. Ann. Tropical Medicine Parasitol. 90, 573-588. https://doi.org/10.1080/00034983.1996.11813087 
Loevinsohn, M.E., 1994: Climatic warming and increased malaria incidence in Rwanda. The Lancet 343, 714-718. https://doi.org/10.1016/S0140-6736(94)91586-5

Martens, P., Kovats R S., Nijhof, S., De Vries, P., Livermore, M.T.J., Bradley, D.J., Cox J., and McMichael, A.J., 1999: Climate change and future populations at risk of malaria. Glob. Environ. Change 9, S89-S107. https://doi.org/10.1016/S0959-3780(99)00020-5

Martens, $P$. and Thomas, $C$., 2005: Climate change and malaria risk: complexity and scaling. Frontis 9 , 3-14. https://doi.org/10.1007/978-1-4020-3929-4_2

Martens, W.J., Niessen, L.W., Rotmans, J., Jetten, T.H., and McMichael, A.J., 1995: Potential impact of global climate change on malaria risk. Environ. Health Perspectives 103, 458. https://doi.org/10.1289/ehp.95103458

Mendis, K., Sina, B.J., Marchesini, P., and Carter, R., 2001: The neglected burden of Plasmodium vivax malaria. Amer. J. Tropical Medicine Hygiene 64, 97-106. https://doi.org/10.4269/ajtmh.2001.64.97

Mihályi, F., and Gulyás, M., 1963: Magyarország csípő szúnyogjai. Akadémiai Kiadó, Budapest. (In Hungarian)

Nakicenovic, N., Alcamo, J., Davis, G., de Vries, B., Fenhann, J., Gaffin, S., and Dadi, Z., 2000: Special report on emissions scenarios: a special report of Working Group III of the Intergovernmental Panel on GCC (No. PNNL-SA-39650). Pacific Northwest National Laboratory, Richland, WA (US), Environmental Molecular Sciences Laboratory (US).

Novikov, Y.M. and Vaulin, O.V., 2014: Expansion of Anopheles maculipennis ss (Diptera: Culicidae) to northeastern Europe and northwestern Asia: Causes and Consequences. Parasites vectors 7, 389. https://doi.org/10.1186/1756-3305-7-389

Olupot-Olupot, P. and Maitland, K., 2013: "Management of severe malaria: Results from recent trials". Advances in Experimental Medicine and Biology. Adv. Experiment. Medicine Biology 764, 24150. https://doi.org/10.1007/978-1-4614-4726-9_20

Oshaghi, M.A., Yaghobi-Ershadi, M.R., Shemshad, K., Pedram, M., and Amani, H., 2008: The Anopheles superpictus complex: introduction of a new malaria vector complex in Iran. Bull. De La Societe De Pathologie Exotique 101, 429-434.

Patz, J.A., and Olson, S.H., 2006: Malaria risk and temperature: influences from global climate change and local land use practices. Proc. Nat. Acad. Sci. 103, 5635-5636. https://doi.org/10.1073/pnas.0601493103

Patz, J.A., Martens, W.J., Focks, D.A., and Jetten, T.H., 1998: Dengue fever epidemic potential as projected by general circulation models of global climate change. Environ. Health Perspective 106, 147. https://doi.org/10.1289/ehp.98106147

Paz, S., and Albersheim, I., 2008: Influence of warming tendency on Culex pipiens population abundance and on the probability of West Nile Fever outbreaks (Israeli Case Study: 2001-2005). EcoHealth 5, 40-48. https://doi.org/10.1007/s10393-007-0150-0

Proft, J., Maier, W.A., and Kampen, H., 1999: Identification of six sibling species of the Anopheles maculipennis complex (Diptera: Culicidae) by a polymerase chain reaction assay. Parasitology Res. 85, 837-843. https://doi.org/10.1007/s004360050642

Reiter, P., 2001: Climate change and mosquito-borne disease. Environ. Health Perspectives 109, 141. https://doi.org/10.1289/ehp.01109s1141

Reusken, C., De Vries, A., Ceelen, E., Beeuwkes, J., and Scholte, E. J., 2011: A study of the circulation of West Nile virus, Sindbis virus, Batai virus and Usutu virus in mosquitoes in a potential highrisk area for arbovirus circulation in the Netherlands, "De Oostvaardersplassen." Europ. Mosquito Bull. 29, 66-81.

Rogers, D.J. and Randolph, S.E., 2000: The global spread of malaria in a future, warmer world. Science 289, 1763-1766. https://doi.org/10.1126/science.289.5485.1763

Roeckner, E., Bäuml, G., Bonaventura, L., Brokopf, R., Esch, M., Giorgetta, M., Hagemann, S., Kirchner, I., Kornblueh, L., Manzini, E., Rhodin, A., Schlese, U., Schulzweida, U., and Tompkins, A., 2003: The atmospheric general circulation model ECHAM 5. Part I: Model description. MaxPlanck-Institut für Meteorologie, Hamburg, Germany.

Roeckner, E., Brokopf, R., Esch, M., Giorgetta, M., Hagemann, S., Kornblueh, L., Manzini, E., Schlese, U., and Schulzweida, U., 2004: The atmospheric general circulation model ECHAM 5. PART II: 
Sensitivity of Simulated Climate to Horizontal and Vertical Resolution. Max-Planck-Institut für Meteorologie, Hamburg, Germany.

Russell, R.C., 1998: Mosquito-borne arboviruses in Australia: the current scene and implications of climate change for human health. Int. J. Parasitology 28, 955-969.

https://doi.org/10.1016/S0020-7519(98)00053-8

Sallares, R., Bouwman, A., and Anderung, C., 2004: The spread of malaria to southern Europe in antiquity: new approaches to old problems. Medical history 48, 311-328. https://doi.org/10.1017/S0025727300007651

Szénási, Z., Vass, A., Melles, M., Kucsera, I., Danka, J., Csohán, A., and Krisztalovics, K., 2003: A malária Magyarországon: előzmények, aktuális állapot és védekezési elvek. Orvosi Hetilap 144, 1011-1018. (In Hungarian)

Shililu, J.I., Tewolde, G.M., Brantly, E., Githure, J.I., C.M. Mbogo, Beier, J.C., Fusco R., and Novak, R.J., 2003: Efficacy of Bacillus thuringiensis israelensis, Bacillus sphaericus and temephos for managing Anopheles larvae in Eritrea. J. Amer. Mosquito Control Assoc. 19, 251-258.

Silbermayr, K., Eigner, B., Joachim, A., Duscher, G.G., Seidel, B., Allerberger, F., Indra, A., Hufnagel, P., and Fuehrer, H.P., 2014: Autochthonous Dirofilaria repens in Austria. Parasit Vectors 7, 226. https://doi.org/10.1186/1756-3305-7-226

Sinka, M.E., Bangs, M.J., Manguin, S., Coetzee, M., Mbogo, C.M., Hemingway, J., Patil, A.P., Temperley, W.H., Gething, P.W. Kabaria, C.W., Okara, R.M., van Boeckel, T., Godfay, H.C.J., Harbach, R.E. and Hay, S.I., 2010: The dominant Anopheles vectors of human malaria in Africa, Europe and the Middle East: occurrence data, distribution maps and bionomic précis. Parasit Vectors. 3, 117. https://doi.org/10.1186/1756-3305-3-117

Șuleșco, T., von Thien, H., Toderaș, L., Toderaș, I., Lühken, R., \& Tannich, E., 2016: Circulation of Dirofilaria repens and Dirofilaria immitis in Moldova. Parasit Vectors. 9, 627. https://10.1186/s13071-016-1916-4

Szénási, Z., Vass, A., Melles, M., Kucsera, I., Danka, J., Csohán, A., and Krisztalovics, K., 2003: Malária Magyarországon: aktuális állapot és védekezési elvek. Orvosi hetilap 144, 1011-1018. (In Hungarian)

Temin, P., 2006: The economy of the early Roman Empire. J. Economic Perspectives, 20, 133-151. https://doi.org/10.1257/089533006776526148

Tóth, S., 2006: A Bakonyvidék csípőszúnyog-faunája (Diptera: Culicidae). Acta Biologica Debrecina, Supplementum Oecologica Hungarica 15, 1-240. (In Hungarian)

Tóth, S., 2004: Magyarország csípőszúnyog-faunája (Diptera: Culicidae). Natura Somogyensis 6. Kaposvár 2004. (In Hungarian)

Tóth, S., and Kenyeres, Z., 2012: Revised checklist and distribution maps of mosquitoes (Diptera, Culicidae) of Hungary. Europ. Mosquito Bull. 30, 30-65.

Trájer, A., Tánczos, B., Hammer, T., Bede-Fazekas, Á., Ranvig, K., Schoffhauzer, J., and Padisák, J., 2017: The complex investigation of the colonization potential of Aedes albopictus (Diptera: Culicidae) in the South Pannonian Ecoregion. Appl. Ecol. Environ.l Res. 15, 275-298. https://doi.org/10.15666/aeer/1501_275298

Trájer, A., and Hammer, T., 2016: Climate-based seasonality model of temperate malaria based on the epidemiological data of 1927-1934, Hungary. Időjárás 120, 331-351.

Trájer, A., Rengei, A., Farkas-Iványi, K., and Bede-Fazekas, Á., 2016: Impacts of urbanisation level and distance from potential natural mosquito breeding habitats on the abundance of canine dirofilariosis. Acta Veterinaria Hungarica 64, 340-359. https://doi.org/10.1556/004.2016.032

Walker, K., and Lynch, M., 2007: Contributions of Anopheles larval control to malaria suppression in tropical Africa: review of achievements and potential. Medic. Veterinary Entomology 21, 2-21. https://doi.org/10.1111/j.1365-2915.2007.00674.x

WHO, 2002: Scaling up insecticide-treated netting programmes in Africa: A strategic framework for coordinated national action. In: Roll Back Malaria. WHO, Geneva, Switzerland, 2002. http://www.eeaa.gov.eg/cmuic/cmuic_pdfs/generalrep/WHO_ScalingInsectNetAfrica.pdf

World Malaria Report, 2015: World Health Organization. December 2015. ISBN 9789241565158. http://apps.who.int/iris/bitstream/handle/10665/200018/9789241565158_eng.pdf;jsessionid=733 AD1D1163752D5CD0CABC86894EDAC?sequence=1 